\title{
The Influence of Perceived Organizational Support and Work Adjustment on the Employee Performance of Expatriate Teachers in Thailand
}

\author{
Khahan Na-Nan ${ }^{1}$, Jamnean Joungtrakul ${ }^{2}$ \& Auemporn Dhienhirun ${ }^{3}$ \\ ${ }^{1}$ Faculty of Business Administration, Rajamangala University of Technology Thanyaburi, Pathum Thani, Thailand \\ ${ }^{2}$ College of Social Sciences, Far East University, South Korea \\ ${ }^{3}$ Faculty of Management Science, Bansomdejchaopraya Rajabhat University, Bangkok, Thailand \\ Correspondence: Khahan Na-Nan, Faculty of Business Administration, Rajamangala University of Technology \\ Thanyaburi, Thanyaburi Pathum Thani, Thailand. Tel: 6-698-922-6200. E-mail: Khahan_n@rmutt.ac.th
}

Received: January 31, 2018

Accepted: February 9, $2018 \quad$ Online Published: February 27, 2018

doi:10.5539/mas.v12n3p105

URL: https://doi.org/10.5539/mas.v12n3p105

\begin{abstract}
This study investigated the influence of perceived organizational support (POS) and work adjustment (WA) on the employee performance (EP) of expatriate English teachers in Thailand. A quantitative method was used; selfevaluation data were collected from 210 expatriate English teachers working in Thailand. The results of the study confirm the hypothesized positive correlational effect of POS and WA on EP. The empirical results confirm the model of investigation consisting of POS, WA and EP developed for testing in the context of Thailand. It also challenges the established connection of POS and WA of EP in a well-understood context of antecedence and is relevant for policymakers, workers, and managers, with implications for future research.
\end{abstract}

Keywords: perceived organizational support, work adjustment, employee performance, expatriate adjustment, Thailand

\section{Introduction}

\subsection{Introduce the Problem}

Research on employee performance (EP) has brought academic attention to a key theme in human resource management, human resource development, organizational development, and organizational behavior. Taiwan et al. (2017) described EP in organizations as a vital construct in research that researchers and practitioners should note, paying attention to its antecedents. Prominent models EP models; for example, Na-Nan \& Pukkeeree (2013) found that organizational factors are independent and influence EP directly and indirectly through job satisfaction. Many researchers have sought ways to promote effective EP by considering employee engagement (Anitha, 2014, Nazir et al., 2017) and perceived organizational support (POS) (Byrne \& Hochwarter, 2008, Karatepe, 2012, Karatepe \& Aga, 2016), as can be seen in psychological and organizational factors. Other studies investigated adjustment as an independent variable for EP as a dependent variable (Awais Bhatti et al., 2013b, Awais Bhatti et al., 2013a). Work adjustment (WA) can be considered to be a process of system performance. Its role in a model of a psychological process, such as adjusting to work, adjusting to the rules environment, and adjusting to coworkers, seems to be as a mediator of effective performance, especially for new workers or expatriates who come to join organizations. However, the studies from which the factors mentioned above appear to ignore of these factors.

\subsection{Explore Importance of the Problem}

Although EP has been well researched and can be found in a growing number of research studies, however, there remain gaps in the literature, and models that have been investigated need to be studied (Jyoti \& Kour, 2017). Among a number of under-researched aspects, Selmer et al. (2011) concluded that the influence of environmental factors was crucial. One such factor is the location to which the new worker or expatriate is assigned. Most studies of workers abroad focus on expatriate managers in Asia and Europe, but there have been no studies focusing on expatriate teachers who come to teach in Southeast Asia, though they play an important role in developing students' knowledge, skills, and attitude to be make them effective. This is a gap that this study attempted to fill. 
This article is structured as follows: first, existing literature on POS, WA, and EP is reviewed; second, hypotheses on the influence of the POS and WA on EP are proposed, derived from existing research; third, the results of our analyses on the effect of POS and WA on EP are provided, and we discuss these results; fourth, theoretical and practical implications of this study are examined; and finally, we note the limitations of the study.

\subsection{Describe Relevant Scholarship}

\section{Employee Performance}

The concept of EP refers to the function of direct knowledge, abilities, skills, and motivation in role-prescribed behavior, for instance in formal job responsibilities (Campbell, 1999). In addition, only actions and behavior related to the goals of the organization are seen as factors in individual job performance (Campbell et al., 1993). Job performance theory indicates a multidimensional construct of job performance that consists of the task dimension (normally deadline-driven production sometimes called the "in-role") and the contextual dimension (sometimes considered discretionary and normally termed the "extra role") (Borman \& Motowidlo, 1993). It has been argued in the expatriate management literature that it is expected for expatriates to work not only on their tasks in the contextual performance dimensions but also on other assignments (e.g., transferring technologies and knowledge). In response to this need, a third EP dimension was proposed by Caligiuri (1997) and Caligiuri \& Day (2000), the specific assignment performance dimension for expatriates. This was well received in the literature. Na-Nan \& Chalermthanakij (2012) and Na-Nan (2016) found that job performance could be defined as the behaviors that employees display at work that amount to the delivery of the outcomes desired by the organization in terms of job quality, quantity, and time.

Job quality is vital to the products and services of an organization and involves meeting set criteria and standards with regard to the procurement, production, quality inspection, and delivery of goods and services. Job quality can also be used as a process control and as a quality determinant within the context of quality control and inspection. Measuring organizational performance requires the measurement of employees' job quality as it reflects their individual attentiveness to work-related activities. Specifically, the job-quality dimension of EP emphasizes instilling an awareness of the significance of product and service quality among the employees.

Job quantity refers to the units of output as a result of employees' behaviors, such as product quantity, waste quantity, and sales figures; measurement of job quantity is essential to the work-related behaviors of an employee, because job quantity (i.e., units of output) reflects the deployment of the employee's physical and mental ability to fulfill responsibilities. Furthermore, job quantity is a straightforward measure of employee job performance: an employee either meets or does not meet the set quantity. Job quantity is impartial, since the measurement is based on tangible and objective results accomplished by each employee.

Job time concerns the amount of time required to complete work-related activities in relation to task difficulty. Employees satisfy job-time goals as long as tasks are carried out accurately and within a reasonable amount of time and the delivery of products or services is on schedule. According to Na-Nan \& Chalermthanakij (2012), job time should be taken into consideration in the measurement of employee job performance. If the time dimension is disregarded, employees may exploit this shortcoming at the expense of the organization's overall performance. In addition, according to Newman (2013), job-time performance drives and directs employees to perform tasks and outcomes in a timely manner.

\section{Perceived Organizational Support}

According to theories of perceived organizational support, POS development is encouraged by the tendency of employees to assign humanlike characteristics to their organization (Eisenberger et al., 2001). As noted in Levinson (1965), agents take actions in the organization that are usually seen as indicators of organizational intent rather than those solely attributed to the personal motives of the agents. This organizational personification that Levinson suggested is abetted by the moral and financial responsibility and legal actions of agents of the organization through organizational norms, policies, and culture that prescribe and provide ongoing behaviors and by organizational agents exerting power over each employee. Using organizational personification, the view of employees in the organization can be traced to their liking or disliking their treatment, as the organization gives indication that it favors or disfavors indication.

The concept of POS stems from the theory of organizational support (Eisenberger et al., 2001), where it indicates an employee's evaluation of the extent that his or her employer values and cares for his or her contributions and well-being (Rhoades et al., 2001). Employees benefit from this evaluation not only in determining what would meet their socio-emotional needs at work but also to evaluate the dispensation of the organization to reward additional efforts. Crucially, human-like tendencies are ascribed by employees to organizations, and via this 
personification treatment as received is interpreted by them at the hands of the organization as an indicator of the organization's orientation to the employee.

Organizational support theorists argue (Eisenberger et al., 2001) that strengthening POS occurs when an employee has a favorable work environment experiences and believes that these favorable experiences were directly enhanced by their decision to work purposefully and voluntarily for the organization (i.e., not from the legal point of view or regulatory forced compliance). The relationship between POS and favorable work experiences is strongest when experiences are attributed toward discretionary acts in the organizational part (Rhoades et al., 2001). An interesting underpinning of organizational support is in social exchange theory, stating that employees tend to dedicate their efforts to the workplace for tangible incentives such as pay and for socio-emotional benefits such as caring, esteem and approval (Mael \& Ashforth, 1992). It has been suggested, due to the reciprocity norm, that high POS levels will engender the employee concern for organizational welfare and its achieving its goals (Rhoades et al., 2001). This relies on the fact that higher levels of POS among employees would also lead to feelings of engagement and therefore an exertion of the required effort in helping the organization work toward the achievement of its objectives.

\section{Work Adjustment}

There are not clear theoretical links between WA and POS. Some studies have investigated the relative POS as a predictor of WA, or PE but they do not test WA as mediator for predicting in the model. Dahling \& Librizzi (2015) commented that WA is a correspondence between the person and environment, focusing on how employees fit into their responsibilities and how the abilities of an employee fit with their job or organizational environment. In addition, Na-Nan \& Pukkeeree (2013) found that work adjustment is the psychological state of a person, the feeling of comfort or relaxation, with the varieties of environment that are experienced. WA is a complex process involved with acculturative stress reduction (Berry, 1992), a gradual amelioration of social skills deficits (Lauring \& Selmer, 2015), a recognition of expectations fitting with the new reality (Ghosh, 2013), or sometimes the culmination of a personal odyssey with a change in a philosophical worldview (Yoshikawa, 1987). A three-dimensional view of WA was proposed by Na-Nan \& Pukkeeree (2013) as follows: (1) adjustment to work: a level of ability or potential according to which people are able to perform their responsibilities perfectly based on their knowledge, skills, and personality to meet the needs and expectations of the organization (Dawis \& Lofquist, 1984); (2) adjustment to rules: the personal ability to accept or adapt to the organization's rules, structure, communication system, commands, and decentralization, which the employee must face in their work; and (3) adjustment to co-workers or networking (Andrews \& Kacmar, 2001, Ashford \& Black, 1996, Raghuram et al., 2001): the personal ability to work with or maintain independence from others in a workplace, a basic need of people who maintain social stability.

Therefore, this research is likely to contribute in the field of human resource management and development in Thailand's circumstance and talking about the discussed variables the gap becomes more prominent.

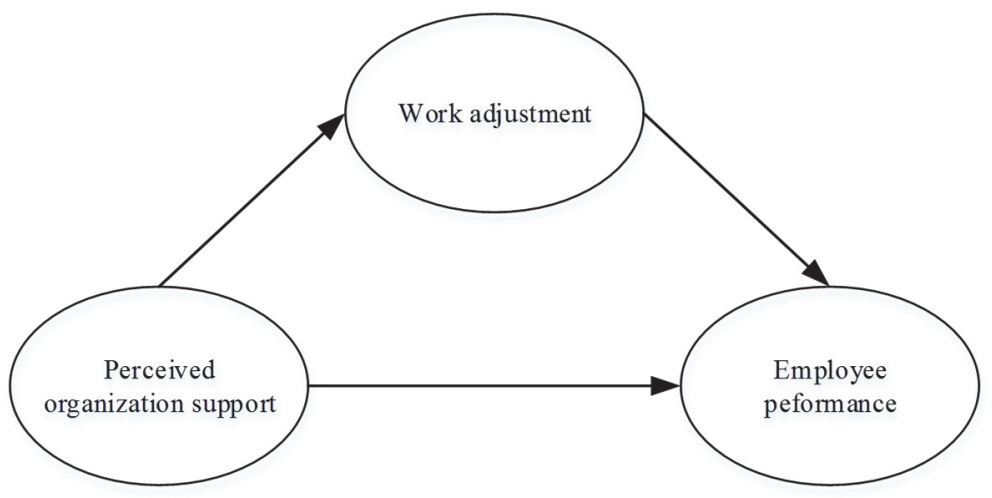

Figure 1. The proposed structural equation model of the influence of perceived organizational support and work adjustment on the employee performance of expatriate teachers in Thailand

\subsection{State Hypotheses and Their Correspondence to Research Design}

The social support literature has found a positive relation between expatriate adjustment and organizational performance (e.g., Kraimer et al., 2001; Qin \& Baruch, 2010). Similarly, social support was proposed by Lee (2010), as it (i.e., POS and supervisor support) may lead to the higher levels of expatriate adjustment and career 
success (i.e., job satisfaction and performance). Moreover, in the literature on expatriates, it has been found that performance is essential in expatriate effectiveness and organizational success (Kim et al., 2008). Performance here means the degree to which an employee can achieve requirements and expectation in his or her employee role (Pulakos et al., 2000). Thus, the following hypothesis is proposed.

\section{H1. There is a positive correlational effect of POS on EP.}

Research has consistently found that for higher levels of social support, workers can overcome psychological distress related to living and working within a host country, which it is otherwise difficult to adjust to (Farh et al., 2010, Iida et al., 2008). Social support is an essential factor in the context of a foreign country assignment (Stroppa $\&$ Spieß, 2011). Previous studies have categorized social support sub-dimensions based on the purposes of the study; for instance, there are two sub-dimensions in social support (i.e., POS and supervisor support) (Kraimer \& Wayne, 2004, Kraimer et al., 2001). Stroppa \& Spieß (2011) have also separated social support into two components (i.e., co-worker and supervisor support). Recently, research has examined social support for individual behavior at work (e.g., Baranik et al., 2010; Kraimer et al., 2001; Lee, 2010). These variables (i.e., POS and supervisor support) are examined as well.

The literature on social support suggests that support comes from multiple sources (i.e., organizations, supervisors, and colleagues) and these can enhance the WA of expatriate personnel by lessening their psychological distress in a multi-cultural setting (Caligiuri \& Lazarova, 2001, Kraimer et al., 2001, Kupka \& Cathro, 2007). An individual's ability to become more capable in providing social support for adjustment positively influences their increased adjustment within cross-cultural environments (Wu \& Ang, 2011). If sufficient support is not given to expatriates by the organization and supervisors, the failure of adjustment is easily noticed from the results of reassignment (Andreason, 2003). On the other hand, expatriates with strong levels of social support perception may have a better ability to become successful in a cross-cultural environment adjustment (e.g., Farh et al., 2010; Shaffer et al., 2006; Wang \& Takeuchi, 2007). Thus, a hypothesis is proposed below.

H2. There is a positive correlational effect of POS on WA.

In a cross-cultural environment, there is a positive relationship of WA to the ability of employees to effectively complete assignments (Ang et al., 2006, Templer et al., 2006) The present study holds that expatriate adjustment to a new cultural setting means the degree of adjustment when individual needs are met in the work setting and in turn performance and job satisfaction are enhanced (Stahl \& Caligiuri, 2005). It has been empirically proven that there is a positive impact of expatriate adjustment on job performance (e.g., Kraimer et al., 2001; Mol et al., 2005). Indeed, it has been indicated by (Wu \& Ang, 2011) that there is a partial effect of cultural adjustment and expatriate performance, but the findings seem inconsistent regarding the assumption of Lee \& Sukoco (2010). In the expatriate adjustment literature, when there is poor adjustment of a worker to a host country, it has been found there is a low ability to adapt to a new cross-cultural environment (Kim et al., 2008) and that poorer performance accompanies greater psychological stress (Lee \& Sukoco, 2010). Thus, it is assumed in this study that when expatriates adjust to a host nation's general environment their performance will not be different than what it is at home. Following the research discussion above, a hypothesis is proposed as follows:

H3. There is a positive correlation effect of WA on EP.

\section{Method}

The following section concerns the analytical strategy and instruments used to collect the responses.

\subsection{Sample and Data Collection}

Expatiate teachers at international schools in Thailand were surveyed. They come from countries all over the world, and they have responsibility for creating lesson plans and implementing their plans for the entire class, to individual students, or in small groups, tracking student progress and presenting this information to parents, creating tests, creating and enforcing classroom rules, working with the school administration to prepare students for standardized tests, and managing students outside the classroom. Thus, we believe that expatiate teachers are suitable participants for testing the current research model.

The decision was made to obtain the sample from the 113 member schools of the International Schools Association of Thailand, at which 1,130 expatriate teachers teach, as the target population. The researchers contacted the principals of the international schools to obtain permission to collect the data. Questionnaires were given to these principals, who then distributed them to the teachers who were the research samples.

\subsection{Participant (Subject) Characteristics}

A total of 300 expatiate teachers were invited to participate in the study, and 245 questionnaires were retuned, with 
a total of 210 usable questionnaires obtained for a $70 \%$ response rate. The number of responses was enough to analyze using the proposed structural equation model (SEM). Hair et al. (2010) stated that the sample size should be 15 times the number of the SEM parameters (i.e., 14 parameters require 210 samples). Of these 210 individuals, a preliminary analysis revealed that $80 \%$ of subjects were female, with an average age of $34.10(\mathrm{SD}=9.01)$ years old and an age range from 20 to 57 years old. A majority of the participants (nearly $57 \%$ ) had at least a high school education, and just over $43 \%$ percent had a college education. The respondents, on average, had almost 8.19 (SD $=5.74$ ) years of work experience.

\subsection{Measurement Scales}

Existing scales were used in the questionnaire. The researchers have also adjusted and developed scales. To measure the POS, we adopted Kurtessis et al. (2017) of questionnaire, with 17 items. Some POS questions were "Your boss is fair in recognizing and aware on individual accomplishments," "Disputes or conflicts are fairly resolved," and "Your boss is fair in recognizing team accomplishments." To measure WA, we used Na-Nan and Pukkeeree (2013) of questionnaire, which includes 12 items. Some WA items were "I understand the methods and ways to work," "I follow the organization rules or disciplines," and "I feel not pressure to work with others." To measure expatriate performance (EP), we used Na-Nan and Chalermthanakij's (2017) questionnaire, composed of 13 items. Some EP questions were "Tasks are performed attentively and correctly," "Quality inspection is conducted prior to the delivery of goods or services," and "Tasks are normally completed on schedule."

The measurements were carried out using a 6-point Likert scale, where 1 denotes strongly disagree and 6 strongly agree. Prior to the collection of data, the questionnaire was tested with a sample of 30 expatriate teachers to determine its reliability and internal consistency, with the content validity of $0.60-1.00$ and Cronbach's $\alpha$ coefficients in the range of $0.862-0.930$.

This study examined the Pearson correlation coefficients between the questionnaire questions for quantitative analysis. The confirmatory factor analysis of the SEM variables was then carried out and the path analysis of the SEM performed. The goodness of fit of the proposed SEM was finally determined.

\section{Results}

To examine research results, the study used a two-stage approach, applying SEM. The key reason for select a twostage approach is its ability to reduce the interactional effects of structural models and measurements (Byrne, 2013). First, data were checked for missing values, outliers, and correlations to fulfill the basic assumptions of SEM (Byrne, 2013, Hair et al., 2010). The main reason for applying correlation was to check whether any variables had a significant influence on the others and check the multicollinearity of the variables. Fortunately, all variables were found to have a significant relationship with the others and there was no multicollinearity found (Table I). The Pearson correlation coefficients of the 12 observable variables were in the range of 0.001 to 0.541 .

Table 1. Correlation analysis

\begin{tabular}{lllllllll}
\hline Variables & POS1 & POS2 & POS3 & WA1 & WA2 & WA3 & EP1 & EP2 \\
\hline POS1 & & & & & & & & \\
POS2 & $0.460^{* *}$ & & & & & & & \\
POS3 & $0.181^{* *}$ & $0.250^{* *}$ & & & & & & \\
WA1 & $0.541^{* *}$ & $0.460^{* *}$ & $0.345^{* *}$ & & & & & \\
WA2 & $0.360^{* *}$ & $0.323^{* *}$ & $0.249^{* *}$ & $0.370^{* *}$ & & & & \\
WA3 & $0.323^{* *}$ & $0.357^{* *}$ & $0.193^{* *}$ & $0.245^{* *}$ & $0.656^{* *}$ & & & \\
EP1 & $0.201^{* *}$ & $0.339^{* *}$ & 0.001 & $0.205^{* *}$ & $0.224^{* *}$ & $0.258^{* *}$ & & \\
EP2 & $0.237^{* *}$ & $0.255^{* *}$ & 0.115 & $0.220^{* *}$ & $0.326^{* *}$ & $0.399^{* *}$ & $0.504^{* *}$ & \\
EP3 & $0.188^{* *}$ & $0.221^{* *}$ & $0.220^{* *}$ & $0.198^{* *}$ & $0.279^{* *}$ & $0.366^{* *}$ & $0.289^{* *}$ & $0.562^{* *}$ \\
\hline
\end{tabular}

Notes: POS1 = fairness; POS2 = supervisor support; POS3 = organizational rewards and job condition; WA1 = adjust to work; WA2 = adjust to rules; WA3 = adjust to co-workers or networking; EP1 = job quality; EP2 = job quantity; $\mathrm{EP} 3=$ job time; ${ }^{* *} \mathrm{p}<0.01$

In checking the multicollinearity of the variables, Hair et al. (2010) stated that correlations among independent variables and correlations that exceed 0.800 can indicate problems. No variable correlation was found over standard (Table I), indicating no multicollinearity. 
In the first phase, we used confirmatory factor analysis (CFA) to check the uni-dimensionality of factors, because the instruments used in the present study were developed on the basis of concepts and theory. To check whether the values of the model fit, standard values of Hair et al. (2010) were applied, that is, the value of $\chi^{2} / \mathrm{df}$ should not be over 3; the higher the value of the comparative fit index (CFI), the higher the model fit; the goodness of fit index (GFI), the adjusted goodness of fit index (AGFI), and the normed fit index (NFI) should be greater than 0.090 . The value of the root mean square error of approximation (RMSEA) should not be over 0.800 .

Table 2. Confirmatory factor analysis

\begin{tabular}{|c|c|c|c|c|}
\hline Item & Factor loading & Cronbach's $\alpha$ & $\mathrm{CR}$ & AVE \\
\hline \multicolumn{5}{|c|}{ Perceived organization support } \\
\hline POS1 & 0.655 & \multirow[t]{3}{*}{0.862} & \multirow[t]{3}{*}{0.756} & \multirow[t]{3}{*}{0.510} \\
\hline POS2 & 0.638 & & & \\
\hline POS3 & 0.752 & & & \\
\hline \multicolumn{5}{|c|}{ Work adjustment } \\
\hline WA1 & 0.529 & \multicolumn{3}{|l|}{0.891} \\
\hline WA2 & 0.737 & & & \\
\hline WA3 & 0.865 & & 0.760 & 0.523 \\
\hline \multicolumn{5}{|c|}{ Employee performance } \\
\hline PE1 & 0.564 & \multirow[t]{3}{*}{0.930.} & 0.746 & \multirow[t]{3}{*}{0.504} \\
\hline PE2 & 0.883 & & & \\
\hline PE3 & 0.644 & & & \\
\hline \multicolumn{5}{|c|}{$\begin{array}{l}\text { Goodness of fit: } \chi^{2}=26.847, \chi 2 / \mathrm{df}=1.790, \mathrm{CFI}=0.979, \mathrm{GFI}=0.974, \mathrm{AGFA}=0.923, \mathrm{NFI}=0.954 \text { and RMSEA } \\
=0.600 .\end{array}$} \\
\hline
\end{tabular}

Additionally, the value of the modification indices and normalized residual were also estimated for model fitness (Byrne, 2013). The modification indices depict the results of the calculation of those relations that are not estimated in the model, while normalized residuals identify the difference between the observed and estimated correlations. All possible modifications were made following the instruction of Hair et al. (2010), because the first analysis did not fit with the model fit index and was consistent with empirical data. After making all the adjustments, the values of test adaptability were found to be $\chi^{2}=26.847, \chi 2 / \mathrm{df}=1.790, \mathrm{CFI}=0.979, \mathrm{GFI}=0.974, \mathrm{AGFA}=0.923, \mathrm{NFI}=$ 0.954 , and RMSEA $=0.600$. All model fit indices are well above the standard values found in Hair et al. (2010).

Table II tabulates the factor loading $(\lambda)$, composite reliability, and average variance extracted (AVE) of each construct. Checking the reliability of the scale, Cronbach's $\alpha$ values were examined, with the standard cut-off limit of 0.700 . Discriminant validity was examined using Kline's (2015) cutoff value of 0.85 as a correlation between variables and composite reliability (CR), while convergent validity was analyzed through AVE. The results in Table II identify that the instrument has convergent and discriminant validity, as the values of CR and AVE are well above 0.60 and 0.50 , respectively (Hair et al., 2010).

\section{Second Phase - Hypothesis Testing}

To investigate both the direct and indirect paths and how the latent variables are related, a structural equation model was used (Byrne, 2013). The hypotheses were examined by investigating path coefficients. All the research hypotheses were supported, showing statistically significant path coefficients $(t<1.980, p<0.010)$.

First, the hypothesized structural equation model was tested (Figure 1). The hypothesized model did not reveal a good fit model index with the cut-off values given by Hair et al. (2010), apart from the value of the root mean square error of approximation $(\mathrm{RMSEA}=0.128)$ and the goodness of fit index $(\mathrm{GFI}=0.905)$. The values of the model fitness were $\chi^{2}=109.747, \chi^{2} / \mathrm{df}=4.573, \mathrm{CFI}=0.844$, AGFA $=0.822, \mathrm{NFI}=0.813$. 


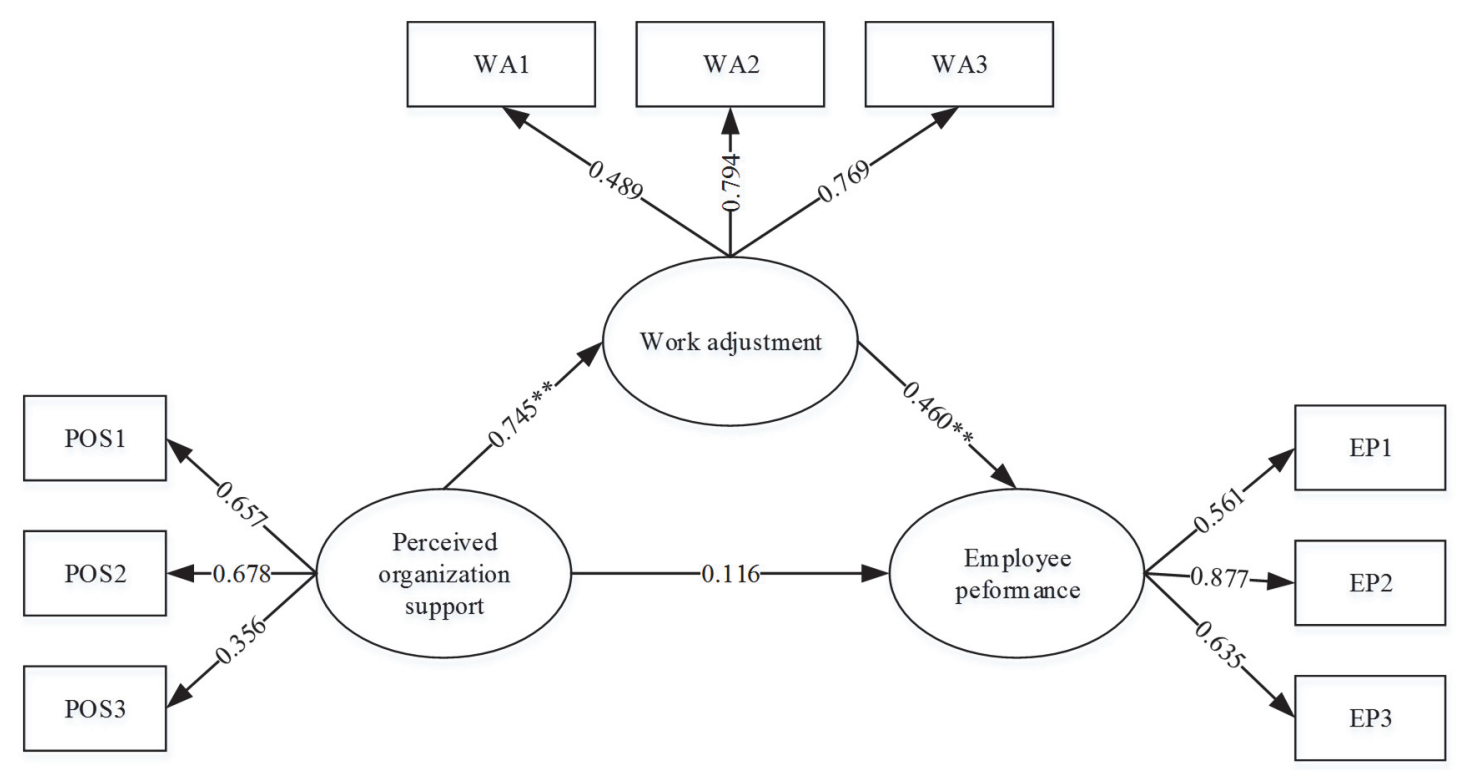

Figure 2. Hypothesized model

Second, an alternate model was also tested, as shown in Figure 2 and was found to be the best fit for all indices, that is, $\chi 2=1.358, \chi 2 / \mathrm{df}=0.339, \mathrm{CFI}=0.999$, GFI $=0.999$, AGFA $=0.985, \mathrm{NFI}=0.998$, and RMSEA $=0.000$. The fitness values of the alternate model were found to be greater than those of the hypothesis model (i.e., $\Delta \chi 2 / \Delta$ df was observed as 4.230). Therefore, the alternate model was accepted and the hypothesized model was rejected.

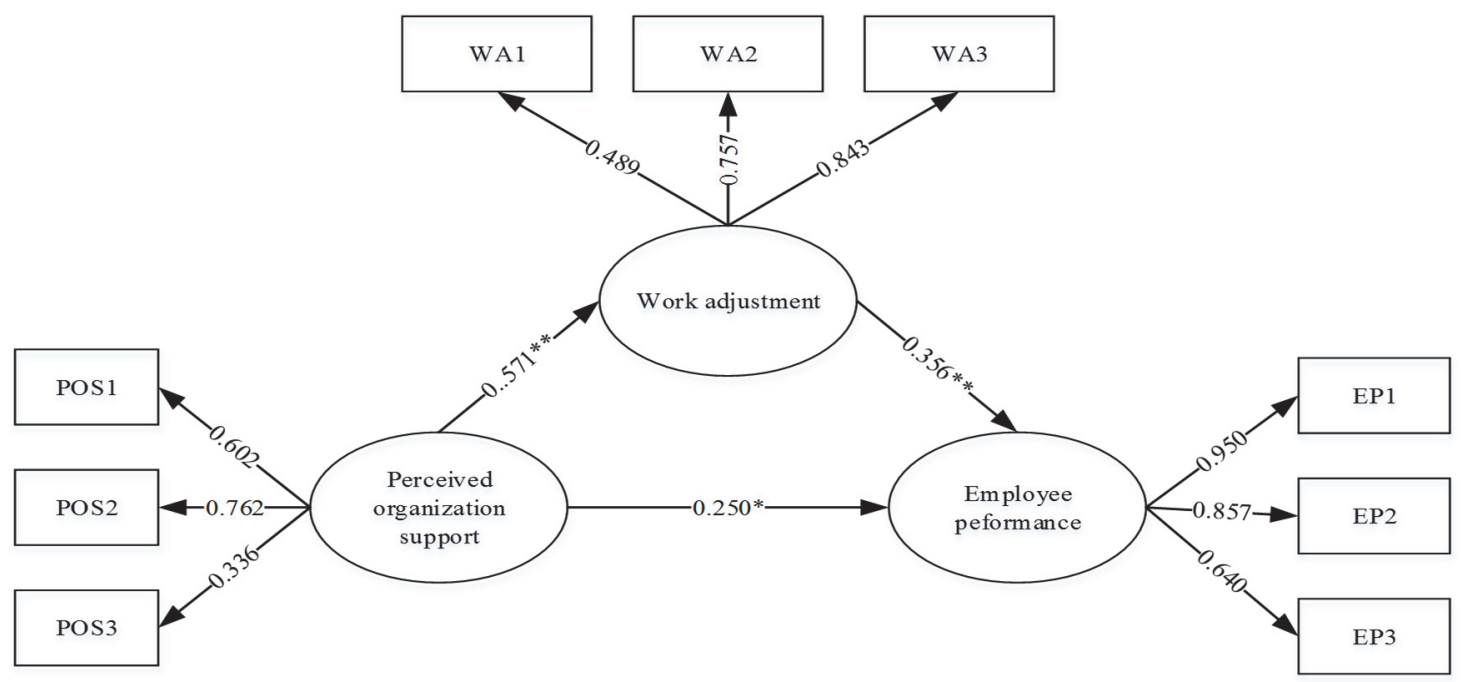

Figure 3. Alternate model

The results revealed that POS had a direct positive influence on EP $(\beta=0.250)$ and on WA $(\beta=0.571)$, which confirmed $H 1$ and $H 2$, respectively. Similarly, the path coefficient of WA on EP was also found to be significant ( $\beta$ $=0.356$ ), which supports $H 3$.

\section{Discussion}

This study develops and investigates a model of the joint correlation between POS and WA on EP. The results of the study show that the POS factor has a positive and significant direct correlation effect of POS on EP among expatriate teachers in Thailand. Similarity, the WA factor was found to have a positive direct correlation effect on EP factor. Meanwhile, it was found that POS has an indirect influence on EP through WA as well. It might be assumed that when employees are supported and encouraged by their organization or provided with resources that 
they need on a continual basis, they will show more WA toward their responsibilities and will deliver services or products to individuals and the organization. The present study suggests that employee POS shows a more comfortable adjustment to work and delivers effective performance to their organizations. The social exchange theory of Blau (1964) also supports the notion that when employees perceive something positive about their organization, they will experience satisfaction or deliver results back to the organization. Consistent with the concept of Eisenberger et al. (2001) and Ahmed et al. (2015) commented that employees who feel genuinely cared for in their socio-emotional needs and well-being by their organization will feel a reciprocating obligation with regard to the fulfilling the organization's objectives.

Arshadi \& Hayavi (2013) found that when organizational staff perceive a high level of encouragement or support from the organization, the employees work more effectively or take more responsibility for their jobs and create high performance for the organization. Kraimer \& Wayne (2004) write on organizational support in the form of POS that the global belief in the value of the contributions by the employee can be given by the firm through care for the employees' well-being. This study showed a positive relationship between the parental company commitment, POS, attempts to complete assignments, and task performance. Similarly, work of Lee (2010) found that POS and supervisor support may lead to higher levels of expatriate adjustment and career success (i.e., job satisfaction and performance).

In addition, this study found that POS has a direct correlational effect on WA. This is consistent with the study of Kawai \& Strange (2014), who commented that employees supported by the organization will let them adjust to work, the atmosphere, and the regulations of organization. Bhatti et al. (2012) wrote that the POS of employees (financial assistance, family support, co-worker support, career path) at high levels helps them adjust to working with their co-worker, organizational rules, or work procedures. This study can supports POS theory as a beneficial provision aiding for two people but with a psychologically buffering intention on the distress for enhancement of emotional well-being. A study on social support showed that with better social support, expatriates avoided psychological distress related to work, living, and interactive aspects in the host country where it was not easy to adjust (Farh et al., 2010, Iida et al., 2008).

Finally, WA directly influences EP. It is assumed that expatriate employees with a high level of WA can deliver the high results or performance to organizations. In the study of Lee et al. (2013) on the effects of social support and transformational leadership on expatriate adjustment and performance, the results show a significantly positive relationship between expatriate adjustment and performance. That study was in line with Wu \& Ang (2011), where a constructive relation between employee's WA and task performance was found, as well as a positive relation between employees' interaction adjustment and contextual performance.

\section{Theoretical Implications}

The concept of POS, based on the theory of Eisenberger et al. (2001), stems from the theory of organizational support, which explained employees' evaluations to the extent that they and their contributions were valued by the employer as well as their well-being (Rhoades et al., 2001). This evaluation is beneficial for employees not only in their determination of things to fulfill their socio-emotional needs at work, but also to assess the dispensation of the organization to reward additional efforts. It is crucial that human-like tendencies be ascribed by employees to the organizations and received treatment is interpreted by them through personification as an employee orientation indicator (Na- Nan, Panich, Thipnete \& Kulsingh, 2016).

This study's results indicate that POS has a statistically significant impact on the WA. Structural equation modeling showed the consistency of findings with previous research and theory; the study gained extremely in POS. Human behavioral phenomena were described to boost awareness of organization directors of the interest of WA and EP. WA is valuable, and organizations should explain regulations, how to work with peers, and the work procedures of the organization for workers interacting with foreign nationals. This can assist the firm in these factors and policy management with the aim to facilitate expatriate adjustment to a new environment.

\section{Practical Implications}

Researchers have previously conducted separate study of different theories and presented their effects on EP. As can be seen from this study, the organization was found to need to successfully implement expatriate performance. One contribution of this study was to seek a positive relationship between adjustment and performance. It is often found that poor adjustment can cause toward the failure of an expatriate. A crucial contribution of the concept of WA was the search for a positive relationship between adjustment and performance where it is normally found that poor adjustment generally leads to worker failure. The results provide initial evidence that expatriates with good work adjustment who can comfortably interact with host-country residents and have better task performance and expatriate contextual performance. Longitudinal study should be conducted to give better evidence related to job 
performance as preceded by adjustment in which recommendations are taken from stress management theories. Relevant performance dimensions were found between expatriate contextual performances and task performance in managerial and technical expatriates.

The focus of organizations should be on the employees; they could benefit from this evaluation to meet socioemotion needs at work and create an organizational dispensation in offering a reward for additional effort (NaNan, Thanitbenjasith, Sanamthong, \& Pukkeeree, 2016; Na-Nan, Chaiprasit \& Pukkeeree, 2017).

\section{Limitation of the Study}

This study had several limitations. Its focus was on the effects of POS and WA on EP. It must be recognized that the researchers attempted to conduct the study to produce accurate results. Limitations that should be noted are as follows. First, the population of expatriate teachers as the target group working in the 113 member schools of the International Schools Association of Thailand may be a unique population. Second, the relation between expatriate adjustment and expatriate performance were examined, but no comparison of the performance levels and different levels of adjustment in different organizations was made. Future research is required on this point. Last, in this study expatriate adjustment was not separated by nationality. Other firms and users should be aware of these points when applying the results of this study.

\section{Acknowledgments}

The authors acknowledge and deeply express their appreciation for the support provided by Dr. Anong Taiwa, the Dean of faculty business administration, Rajamangala University of Technology Thanyaburi and co-researchers during the data collection and verification of research work.

\section{References}

Ahmed, I., Nawaz, Muhammad, M., Ali, G., \& Islam, T. (2015). Perceived organizational support and its outcomes: A meta-analysis of latest available literature. Management Research Review, 38(6), 627-639.

Andreason, Aaron W. (2003). Expatriate adjustment to foreign assignments. International Journal of Commerce and Management, 13(1), 42-60.

Andrews, M. C., \& Kacmar, K. M. (2001). Discriminating among organizational politics, justice, and support. Journal of Organizational Behavior, 22(4), 347-366.

Ang, S., Van Dyne, L., \& Koh, C. (2006). Personality correlates of the four-factor model of cultural intelligence. Group \& Organization Management, 31(1), 100-123.

Anitha, J. (2014). Determinants of employee engagement and their impact on employee performance. International Journal of Productivity and Performance Management, 63(3), 308-323.

Arshadi, N., \& Hayavi, G. (2013). The effect of perceived organizational support on affective commitment and job performance: mediating role of OBSE. Procedia-Social and Behavioral Sciences, 84, 739-743.

Ashford, S. J., \& Black, J. S. (1996). Proactivity during organizational entry: The role of desire for control. Journal of Applied Psychology, 81(2), 199-214.

Awais, B., Muhammad, K. S., \& Mohamed, B. M. (2013a). Effects of individual characteristics on expatriates' adjustment and job performance. European Journal of Training and Development, 37(6), 544-563.

Awais, B., Muhammad, M. B., \& Rageh, I. A. (2013b). Expatriates adjustment and job performance: an examination of individual and organizational factors. International Journal of Productivity and Performance Management, 62(7), 694-717.

Baranik, L. E., Roling, E. A., \& Eby, L. T. (2010). Why does mentoring work? The role of perceived organizational support. Journal of vocational behavior, 76(3), 366-373.

Berry, J. W. (1992). Acculturation and adaptation in a new society. International migration, 30(s1), 69-85.

Bhatti, M. A., Sundram, V. P. K., \& Hoe, C. H. (2012). Expatriate job performance and adjustment: Role of individual and organizational factors. Journal of Business \& Management, 1(1), 29-39.

Blau, P. M. (1964). Exchange and power in social life: Transaction Publishers.

Borman, W. C., \& Motowidlo, S. J. (1993). Expanding the criteria domain to include elements of contextual performance. In N Schmitt \& W. C Borman (Eds.), Personnel selection in organizations (pp. 71-98). San Francisco: Jossey-Bass.

Byrne, B. M. (2013). Structural equation modeling with Mplus: Basic concepts, applications, and programming: 
Routledge.

Byrne, Z. S., \& Hochwarter, W. A. (2008). Perceived organizational support and performance: Relationships across levels of organizational cynicism. Journal of Managerial Psychology, 23(1), 54-72.

Caligiuri, P. M. (1997). Assessin expatriate success: Beyong just "being there" In Saunders D. M. \& Z. Aycan (Eds.), New approaches to employee management (Vol. 4, pp. 117-140). Greenwich, CT: JAI Press.

Caligiuri, P. M., \& Day, D. V. (2000). Effects of Self-Monitoring on Technical, Contextual, and AssignmentSpecific Performance A Study of Cross-National Work Performance Ratings. Group \& Organization Management, 25(2), 154-174.

Caligiuri, P. M., \& Lazarova, M. (2001). Strategic repatriation policies to enhance global leadership development. Developing global business leaders, pp. 243-256.

Campbell, J. P. (1999). The definition and measurement of performance in the new age. In D. R. Ilgen \& E. D. Pulakos (Eds.), The changing nature of performance: Implications for staffing, motivation. and development (pp. 339-429). San Francisco: Calif: Jossey-Bass.

Campbell, J. P., McCloy, R. A., Oppler, S. H, \& Sager, C. E. (1993). A theory of performance. In N Schmitt \& W. C. Borman (Eds.), Personnel selection in organizations (pp. 35-70). San Francisco: Jossey-Bass.

Dahling, J. J., \& Librizzi, U. A. (2015). Integrating the theory of work adjustment and attachment theory to predict job turnover intentions. Journal of Career Development, 42(3), 215-228.

Dawis, R. W., \& Lofquist, L. H. (1984). A Psychological Theory of Work Adjustment. Minneapoles, MN Universityof Minnesota Press.

Eisenberger, R., Armeli, S., Rexwinkel, B., Lynch, P. D., \& Rhoades, L. (2001). Reciprocation of perceived organizational support. Journal of applied psychology, 86(1), 42-51.

Farh, C. I. C., Bartol, K. M., Shapiro, D. L., \& Shin, J. (2010). Networking abroad: A process model of how expatriates form support ties to facilitate adjustment. Academy of Management Review, 35(3), 434-454.

Ghosh, A. (2013). Interpersonal cross-cultural contact: Exploring the role of cultural encounters as antecedent to cultural competence at workplace. Management and Labour Studies, 38(1-2), 81-101.

Hair, J. F., Black, W. C., Babin, B. J., Anderson, R. E., \& Tatham, R. L. (2010). Multivariate data analysis (7 ed): Prentice hall Upper Saddle River, NJ.

Iida, M., Seidman, Gwendolyn, Shrout, P. E., Fujita, K., \& Bolger, N. (2008). Modeling support provision in intimate relationships. Journal of Personality and Social Psychology, 94(3), 460-478.

Jyoti, J., \& Kour, S. (2017). Factors affecting cultural intelligence and its impact on job performance: role of crosscultural adjustment, experience and perceived social support. Personnel Review, 46(4), 767-791.

Karatepe, O. M. (2012). Perceived organizational support, career satisfaction, and performance outcomes: a study of hotel employees in Cameroon. International Journal of Contemporary Hospitality Management, 24(5), 735-752.

Karatepe, O. M., \& Aga, M. (2016). The effects of organization mission fulfillment and perceived organizational support on job performance: The mediating role of work engagement. International Journal of Bank Marketing, 34(3), 368-387.

Kawai, N., \& Strange, R. (2014). Perceived organizational support and expatriate performance: Understanding a mediated model. The International Journal of Human Resource Management, 25(17), 2438-2462.

Kim, Kwanghyun, Kirkman, B. L., \& Chen, G. (2008). Cultural intelligence and international assignment effectiveness. Handbook of cultural intelligence: Theory, measurement, and applications, pp. 71-90.

Kline, R. B. (2015). Principles and practice of structural equation modeling: Guilford publications.

Kraimer, M. L., \& Wayne, S. J. (2004). An examination of perceived organizational support as a multidimensional construct in the context of an expatriate assignment. Journal of Management, 30(2), 209-237.

Kraimer, M. L., Wayne, S. J., \& Jaworski, R. A. (2001). Sources of support and expatriate performance: The mediating role of expatriate adjustment. Personnel Psychology, 54(1), 71-99.

Kupka, B., \& Cathro, V. (2007). Desperate housewives-social and professional isolation of German expatriated spouses. The International Journal of Human Resource Management, 18(6), 951-968.

Kurtessis, J. N., Eisenberger, R., Ford, M. T., Buffardi, L. C., Stewart, K. A., \& Adis, C. S. (2017). Perceived 
organizational support: A meta-analytic evaluation of organizational support theory. Journal of Management, 43(6), 1854-1884.

Lauring, J., \& Selmer, J. (2015). Job engagement and work outcomes in a cognitively demanding context: The case of expatriate academics. Personnel Review, 44(4), 629-647.

Lee, L. Y. (2010). Multiple intelligences and the success of expatriation: The roles of contingency variables. African Journal of Business Management, 4(17), 3793-3804.

Lee, L. Y., \& Sukoco, B. M. (2010). The effects of cultural intelligence on expatriate performance: The moderating effects of international experience. The International Journal of Human Resource Management, 21(7), 963981.

Lee, L. Y., Veasna, S., \& Wu, W. Y. (2013). The effects of social support and transformational leadership on expatriate adjustment and performance: The moderating roles of socialization experience and cultural intelligence. Career Development International, 18(4), 377-415.

Levinson, H. (1965). Reciprocation: The relationship between man and organization. Administrative Science Quarterly, 370-390.

Mael, F., \& Ashforth, B. E. (1992). Alumni and their alma mater: A partial test of the reformulated model of organizational identification. Journal of organizational Behavior, 13(2), 103-123.

Mol, S. T., Born, M. P., Willemsen, M. E., \& Van, D. M., Henk, T. (2005). Predicting expatriate job performance for selection purposes A quantitative review. Journal of Cross-Cultural Psychology, 36(5), 590-620.

Na-Nan, K. (2016). Performance management system of SMEs in Thailand. International journal of Economics Research, 13(4), 1641-1658.

Na-Nan, K., \& Chalermthanakij, K. (2012). A causal model of affecting factor on organizational commitment and employee performance factors. Rmutt Global Busines and Economics Review, 7(1), 145-168.

Na-Nan, K., \& Pukkeeree, P. (2013). Influence of job characteristics and job satisfaction effect work adjustment for entering labor market of new graduates in Thailand. International Journal of Business and Social Science, 4(2). 95-103.

Na-Nan, K., Chaiprasit, K., \& Pukkeeree, P. (2017). Influences of workplace environment factors on employees' training transfer. Industrial and Commercial Training, 49(6), 303-314.

Na-Nan, K., Panich, T., Thipnete, A., \& Kulsingh, R. (2016). Influence of job characteristics, organizational climate, job satisfaction and employee engagement that affect the organizational citizenship behavior of teachers in Thailand. The Social Sciences, 11(18), 4523-4533.

Na-Nan, K., Thanitbenjasith, P., Sanamthong, E., \& Pukkeeree, P. (2016). The Relationship between organizational cultures and courageous followership behaviors: That's the relationship and why does it matter. International Business Management, 10(8), 4384-4390.

Nazir, O., \& Islam, Jamid Ul. (2017). Enhancing organizational commitment and employee performance through employee engagement: An empirical check. South Asian Journal of Business Studies, 6(1), 98-114.

Newman, D. (2013). Time to evaluate great expectations. Employers' Law, 1(1), 20-21.

Pulakos, E. D., Arad, S., Donovan, M. A., \& Plamondon, K. E. (2000). Adaptability in the workplace: development of a taxonomy of adaptive performance. Journal of applied psychology, 85(4), 612-624.

Qin, Chenyi, \& Baruch, Y. (2010). The impact of cross-cultural training for expatriates in a Chinese firm. Career Development International, 15(3), 296-318.

Raghuram, Su., Garud, R., Wiesenfeld, B., \& Gupta, V. (2001). Factors contributing to virtual work adjustment. Journal of Management, 27(3), 383-405.

Rhoades, L., Eisenberger, R., \& Armeli, S. (2001). Affective commitment to the organization: the contribution of perceived organizational support. Journal of Applied Psychology, 86(5), 825-836.

Selmer, J., Suutari, V., Kittler, M. G., Rygl, D., Mackinnon, A., \& Wiedemann, K. (2011). Work role and work adjustment in emerging markets: A study of German expatriates in CEE countries and Russia. Cross Cultural Management: An International Journal, 18(2), 165-184.

Shaffer, M. A., Harrison, D. A., Gregersen, H., Black, J. S., \& Ferzandi, L. A. (2006). You can take it with you: individual differences and expatriate effectiveness. Journal of Applied Psychology, 91(1), 109-125. 
Stahl, G. K., \& Caligiuri, P. (2005). The effectiveness of expatriate coping strategies: the moderating role of cultural distance, position level, and time on the international assignment. Journal of Applied Psychology, 90(4), 603-615.

Stroppa, C., \& Spieß, E. (2011). International assignments: The role of social support and personal initiative. International Journal of Intercultural Relations, 35(2), 234-245.

Taiwan, A., Na-Nan, Khahan, \& Ngudgratoke, S. (2017). The effects of personality and transformational leadership on expatriate adjustment and expatriate performance. International Journal of Applied Business and Economic Research, 15(22), 223-234.

Templer, K. J., Tay, C., \& Chandrasekar, N. (2006). Motivational cultural intelligence, realistic job preview, realistic living conditions preview, and cross-cultural adjustment. Group \& Organization Management, 31(1), 154-173.

Thongpull, K., Rugchoochip, K., \& Na-Nan, Khahan. (2016). A causal model of job characteristics, transformational leadership, and perceived organizational support effects on organizational commitment and organizational citizenship behavior. Suthiparithat, 30(93), 131-145.

Wang, M., \& Takeuchi, R. (2007). The role of goal orientation during expatriation: a cross-sectional and longitudinal investigation. Journal of Applied Psychology, 92(5), 1437-1445.

Wu, P. C., \& Ang, S. H. (2011). The impact of expatriate supporting practices and cultural intelligence on crosscultural adjustment and performance of expatriates in Singapore. The International Journal of Human Resource Management, 22(13), 2683-2702.

\section{Copyrights}

Copyright for this article is retained by the author(s), with first publication rights granted to the journal.

This is an open-access article distributed under the terms and conditions of the Creative Commons Attribution license (http://creativecommons.org/licenses/by/4.0/). 